\title{
Developing Education Supervision in Private Madrasah Ibtidaiyah
}

\author{
Moh. Adib ${ }^{1}$, Weni Tria Anugrah Putri ${ }^{2}, \mathrm{Ahmadi}^{3}$ \\ IAIN Ponorogo $0^{1,2,3}$ \\ \{adibtubanpacitan@gmail.com¹,wtriaanugrahputri@iainponorogo.ac.id²,Ahmadi@iainponorogo.ac.id ${ }^{3}$ \}
}

\begin{abstract}
Academic supervision is one of the strategic programs in improving the quality of learning at MI al-Huda Pacitan. This is the basis for the research objectives in this study, namely to: (1) identify madrasah leaders in analyzing learning needs, (2) supervising learning devices, (3) implementing academic supervision of madrasah leaders, and (4) follow-up after academic supervision. at MI Al-Huda Pacitan. This research used a qualitative approach, with a case study design. The research data collection was carried out through participant observation, in-depth interviews and documentation. The data analysis method used was the source triangulation method and the technical triangulation method. The conclusions of this study are, first, MI al-Huda conducted a learning needs analysis by analyzing: a) stakeholder expectations, b) student character, and c) instructional media. Second, the supervision of learning devices is carried out by a) conveying the standards / standards of learning devices from the Ministry of Education and Culture, b) giving examples of making learning devices, and c) examining learning devices before implementing learning and during the implementation of classroom observations of academic supervision. Third, the implementation of academic supervision is carried out by a) conducting class visits, class observations and teacher meetings. Fourth, the follow-up of applied academic supervision is a) direct and indirect coaching in the form of internal training (in house trining) b) consolidation in the form of research assignments (PTK).
\end{abstract}

Keywords: Academic Supervision; Quality Improvement; Learning Quality

\section{Pendahuluan}

Education is an integral part of human life. Humans can foster their personality through developing their potential according to the values in society and culture. Thus, education is a conscious and planned effort to create an atmosphere of learning and the learning process. It is intended that students are able to develop their potential to have religious spiritual strength, self-control, personality, intelligence, noble morals, and skills needed by themselves, society, nation and state $[1, \mathrm{hlm} .2]$.

The existence of madrasas is important to develop human potential. Madrasah is a formal educational institution that organizes teaching and learning process activities as an effort to 
achieve educational goals. The person in charge of the teaching and learning process is the teacher. The learning outcomes of students are of course determined by the role of the teacher

A madrasah teacher needs guidance and direction as well as assistance from others who have the ability to overcome the difficulties / obstacles they face. This is so that teachers can develop their potential. Thus it is hoped that the professional competence can increase. One effort that can be made to overcome this is the implementation of academic supervision.

Academic supervision is a part of the quality management of education carried out by the principal and madrasah supervisors[2]. This is in accordance with the Regulation of the Minister of National Education No. 12 of 2007 concerning Standards for School / Madrasah Supervisors [2] and Regulation of the Minister of National Education No. 13 of 2007 concerning the Standards for Principals of Schools / Madrasah [3, hlm. 13]. The main activity of supervision is to provide guidance to schools / madrasahs in general and teachers in particular. This aims to improve the quality of learning. With this increase, it is hoped that it can improve student achievement, the quality of school graduates will also increase

Academic supervision programs occupy a very important position. One of them is the application of knowledge about providing assistance and guidance to teachers in planning and implementing job and professional advancement. This is carried out by making use of available resources. This contrasts with the 2010 Ministry of National Education data showing that as many as $70 \%$ of the 250 thousand school principals in Indonesia are still reluctant to carry out their role as supervisors. [4, p. 78-79] The author believes that this opinion is true. Another source of corroborating data is news published in the monthly magazine of the East Java Provincial Education Office. The media is the magazine "Media". In detail, the news is written in the October 2011 edition of the readers' opinion rubric on the topic "Principal Supervision". Based on this data, there were eight teachers from five districts in East Java whose articles were published in this edition of the magazine. One of the teachers of SMAN 1 Plosoklaten - Kediri stated that the supervision carried out by the principal so far was only a formality.

\section{Result and Discussion}

The main problem is the principal who acts as the actor of academic supervision. More precisely, there are several madrasah principals who carry out academic supervision but are only documentative. This means that it is only limited to examining learning devices. There are also madrasah principals who implement it, but only a small proportion of the number of teachers teaching in their institutions. Several reasons the authors conducted research at MI Al-Huda Pacitan, namely first, MIal-Huda is a small part of private MI with a Madrasah principal who carries out academic supervision with various and strategic forms of technique; second, MI al-Huda carries out academic supervision, one of which uses a strategy that is slightly different from the existing theory

Based on the above background, the authors are interested in researching academic supervision at MI Al-Huda Pacitan. The hope is that researchers have a positive contribution to other schools / madrasahs (especially Elementary Schools / Madrasah Ibtidaiyah). Of course this refers to the madrasah ibtidaiyah, whose learning quality is still low. So that in this era of intense competition, all MI or SD, especially in Pacitan can compete healthily and are able to live and remain sustainable. In accordance with the focus of this research, it is entitled "Academic Supervision in Improving the Quality of Learning at MI Al-Huda Pacitan". Hopefully it is useful and makes a real contribution to the world of education. 


\subsection{Analysis of Competency Needs of Madrasah Graduates}

Academic supervision is part of the supervision carried out by the Madrasah Principal. This aims to provide guidance, supervision, assessment, control and giving examples to teachers to improve the quality of learning. This is in accordance with the opinion of Lantip and Sudiyono who stated that implementing academic supervision in order to improve learning is one of the duties of the supervisor (school / madrasah principal) [5, p. 101]. Likewise, what was conveyed by Daryanto and Tutik, the supervisor or actor of academic supervision is the principal [6, p. 37]. The researcher analysis of the data obtained in the field is as follows.

\section{a) Analysis of Stakeholder Expectations}

The Missions of MI al-Huda: 1) Carrying out practical and theoretical Islamic religious education, 2) Implementing and cultivating Islamic behavior in daily life, 3) Organizing quality learning based on science and technology, and 4) Carrying out student development based on talents and abilities, and 5) Instilling student patriotism through ceremonies and national holidays. This mission was born from the expectations of madrasa stakeholders, namely: first, at point a, Islamic religious education is practically and theoretically applied by realizing education, among others, prayer theory and prayer practice. Madrasahs have the hope that MI al-Huda graduates can establish prayers properly and correctly. Second, apply and cultivate Islamic behavior in everyday life. This mission was born from stakeholders, especially parents. This is very natural because currently any parent is worried about the moral crisis that has hit. Third, organizing quality learning based on science and technology. This point implicitly arises from the madrasa and the environment. In this digital era, humans are highly required to master science and technology. We can prove the demands regarding mastery of science and technology and find it in everyday life. Fourth, carry out student development based on talents and abilities. This point is what most needs a creative handler. Fifth, instill student patriotism through ceremonies and national holidays. This is a concern of madrassas and the government in the midst of a condition where there is a scarcity of patriotic people. The five of these missions are summarized in the objectives of the madrasa. The objectives of the madrasah are also part of the national goals stated in the Republic of Indonesia Law Number 20 of 2003 concerning the National Education System article 3. All of the above goals are included or formulated in the syllabus. Academic supervision carried out by the Head of Madrasah includes guiding teachers in compiling a syllabus for each subject development area in schools / madrasahs[5, p. 82-83].

According to researchers, the needs analysis conducted by the head of Madrasah is to pay attention to the objectives of national education by taking into account the needs or expectations from within and outside. The expectations from within are the expectations of the madrasah itself or the foundation and expectations from the outside are the expectations of the community, especially the parents / guardians of students.

\section{b) Student Analysis}

Abdul Majid said that the learning strategy includes the use of approaches, methods and techniques, media forms, learning resources, grouping students, between students, and between students and their environment as well as efforts to measure the process, results and / or impact of learning activities [7, p. 6]. 
The analysis of students at MI al-Huda produces action in the learning it carries out by adjusting the use of approaches, methods and techniques, media forms, learning resources, grouping students, between students, and between students and their environment as well as measuring efforts towards processes, results and or the impact of learning activities as said by Abdul Majid. The condition of students with the goals of madrasah education and national education goals must be synchronized in learning with appropriate methods and strategies. Majid said that the teaching method is one of the elements in the learning strategy [7, p. 21].

\section{c) Analysis of Learning Media}

Instructional media is very dominant in the absorption of material delivered by the teacher. The suitability of the media with the teaching material is one of the points in the RPP and its implementation process. Among the existing media, projectors are the learning media at MI al-Huda. Therefore, the teacher in the school must be able to operate and deliver the material properly and correctly with a projector

The head of MI al-Huda said LCD (projectors) were a priority learning medium and were able to attract interest and restore enthusiasm for students. Hamalik said that the use of instructional media in the teaching and learning process can generate new desires and interests, generate motivation and stimulation of learning activities and even bring psychological influences on students. Arsyad also added that learning media can also help students improve understanding, present data in an interesting and reliable manner, facilitate data interpretation, and condense information [8, p. 20-21].

According to researchers, the Head of MI al-Huda made the selection in using learning media. And the option that best suits the current conditions is already being used in the madrasah. The teacher-student relationship remains an important element in today's modern education system. The teacher must always be present to present lesson materials with the help of any media so that some benefits can be achieved.

\subsection{Academic Supervision in Developing Learning Quality}

\section{a) Standards / Benchmarks for Making Learning Devices}

Teaching planning is designed in the form of learning tools. The teacher makes learning tools before learning begins in the classroom. The learning device is tailored to the learning needs. The principal of MI al-Huda emphasized that the substance of the learning equipment was in accordance with the vision and mission of the madrasa, the character of students, and the learning media

Regarding the format and the points follow the rules of the National Education Office. Permendikbud Number 22 of 2016 concerning Process Standards has set standards or benchmarks for learning tools both syllabus and lesson plans. The points listed for the lesson plan are: 1) school identity, namely the name of the educational unit, 2) the identity of the subject or theme / sub-theme, 3) class / semester, 4) subject matter, 5) time allocation, 6) formulated learning objectives based on $\mathrm{KD}$, 7) basic competencies and indicators of competency achievement, 8) learning materials, 9) learning methods, 10) learning media, 11) learning resources, 12) learning steps are carried out through preliminary, core and closing stages, and $\mathrm{m}$ ) assessment of learning outcomes [8].

The head of MI al-Huda does not set standards or standards in the form and model of making learning devices. The head of the Madrasah pays more attention to the suitability of 
the contents of the device with the condition of the students, the existing media and the learning process. This is as stated by Suharsimi that academic supervision focuses on observations on academic problems, namely those that are directly within the scope of learning activities carried out by teachers to help students while in the learning process [9].

\section{b) Leaders in Guiding Teachers to Make Learning Device}

Academic supervision is professional assistance and guidance or guidance for teachers in carrying out instructional tasks to improve learning and teaching by continuously stimulating, coordinating and guiding as part of improving the quality of learning. The head of MI al-Huda always reminds and instills awareness in his teachers to improve or improve the quality of learning at every teacher meeting which is held every month

The head of the Madrasah has carried out his duties as a supervisor as stated by Lantip, that the principal guides the teacher in compiling the syllabus for each subject development area in schools / madrasahs and guides the teacher in preparing RPP for each area of subject development in schools / madrasahs [5, p. 82-83]. Carrying out supervisor duties as a guide is a task that must be carried out by the principal.

\section{c) Examination of Learning Devices}

The head of MI al-Huda checks the learning devices a week before the lesson. This examination functions to control the teacher in carrying out his duties with a device that is used as a guideline. Suryosubroto said, besides being useful as a means of control, teaching preparation is also useful as a guide for the teacher himself [10, p. 23]. The head of MI alHuda also corrects errors as needed if they are in the syllabus so that they are really in accordance with the learning program.

Examination of learning devices conducted by the head of Madrasah is to improve the quality of learning. This shows that the principal is carrying out what the supervisor's specific goals are. Suharsimi said, among the specific goals of academic supervision is to improve the quality of teacher performance in schools so that they succeed in helping and guiding students to achieve learning and personal achievements as expected and increasing the effectiveness of the curriculum so that it is efficient and well implemented in the learning process at school [9].

In addition, the examination carried out by the Head of Madrasah is to coordinate the suitability of learning components. In accordance with what was conveyed by Wahyuni and friends, that a lesson plan needs to be done to coordinate learning components, namely: basic competencies, subject matter, indicators, and class-based assessments [11].

\section{d) Implementation of Academic Supervision at MI al-Huda}

In an effort to improve the quality of learning, the Head of MI al-Huda is very keen to carry out academic supervision at the madrasah he leads. The head of madrasah predicts that without academic supervision, the quality of learning in his madrasah will decline. The supervision carried out by the Head of MI al-Huda is aimed at improving the quality of learning in his madrasah. The purpose of academic supervision as stated by Suharsimi is to develop better and better quality teaching and learning situations, especially those carried out by teachers in learning activities[9].

Madrasah principals recognize that madrasah principals must have the skills to carry out academic supervision. As stated by Gwyn, who was quoted by Lantip, that every principal of a 
school / madrasah must have technical skills in the form of the ability to apply appropriate supervision techniques in carrying out academic supervision [5, p. 101]. With academic supervision carried out by the Principal of Madrasahs, the quality of learning at MI al-Huda has increased from year to year. At least, not until the quality of learning has decreased. The main concern of supervisors is how the students who learn, with or without the help of the teacher directly.

\section{e) Academic Supervision Implementation Time}

The timing of the implementation of academic supervision at MI al-Huda was programmed. However, the implementation of class visits is carried out from time to time with considerations and strategies, namely so that the head of the Madrasah can find out the actual situation of learning carried out by the teacher without making up. So that this can accustom the teacher to always prepare as well as possible[12, hlm. 54]. And the negative side of the teacher becomes nervous because suddenly the teacher approaches and arises the prejudice from the teacher that he is being assessed and the result is definitely not satisfactory [12].

Then academic supervision of classroom observation techniques is carried out every February and March in the even semester and August and September in the odd semester. The principal of the madrasah conveyed to his subordinate teachers a month before the supervision began. With a strategy like this, all teachers get ready to be supervised. Even though the notification of the head of the madrasa is made like that, all the teachers carry out the preparations to be supervised with pleasure and with full stability. The head of MI al-Huda holds the principles of supervision. The principles of supervision that must be carried out according to Sah Arti are: 1) the principles of cooperation, 2) scientific principles, 3) democratic principles, and 4) constructive and creative principles [12].

The detailed schedule for the implementation of classroom observations is not notified with the consideration of the Madrasah Principal, namely that the educators he leads are always ready to be observed by the head of the madrasah at any time. Or with the aim of accustoming the teacher to always be prepared as well as possible [12, hlm. 54].

\section{f) Aspects Observed in the Implementation of Supervision}

The implementation of academic supervision at MI al-Huda refers to the quality of learning in the classroom as the goal of academic supervision. In making classroom observations, in academic supervision there are aspects that are very important to note. The aspects that become the assessment include: 1) pre-learning, 2) opening learning, 3) core learning activities, 4) utilization of learning media, 5) assessment of learning processes and outcomes, 6) use of language, and 7) closing.

In addition, learning activities involve interrelated components with each other and support in achieving the learning objectives that have been set in the learning program [13, p. 77]. The components in the learning are 1) teacher, 2) students, 3) methods, 4) environment, 5) media and 6) infrastructure [13].

\section{g) Academic Supervision Techniques}

The findings of the field data show that the academic supervision carried out by the head of MI al-Huda is: 1) with class visits carried out without prior notification, 2) by observing the 
class in (when the teacher is teaching) complete with the instruments, 3) by holding a meeting held every month

First, the academic supervision carried out at MI al-Huda is that the Principal of the Madrasah visits the class without prior notification. This kind of academic supervision practice is intended so that the head of the Madrasah can find out the actual situation of the learning carried out by the teacher without making up. So that this can accustom the teacher to always prepare as well as possible [12, hlm. 54].

Although this is done by the head of the Madrasah, teachers have no objections to the academic supervision of the technique. Because according to Sah Arti this technique has a negative side in the form of the teacher becoming nervous because suddenly he is approached and there is a prejudice from the teacher that he is being assessed and the result is definitely unsatisfactory [12].

Second, academic supervision techniques in the form of classroom observation. This technique is carried out by stages in the form of observation and post-observation. In the implementation of observations, the Principal of Madrasah observes the learning process in detail about aspects of learning and learning tools. During the observation, the Madrasah Principal notes important things that need to be discussed during post-observation. Sah understanding says that classroom observation has the aim of obtaining as objective data as possible to analyze the difficulties faced by teachers in efforts to improve the quality of learning, to change teaching methods for the better and will be able to have a positive influence on student learning progress $[12, \mathrm{hlm}$. 54]. In addition, according to Daryanto and Tutik, the purpose of classroom observation is to observe a situation or event that is taking place in the class concerned [14, hlm. 159].

Based on the existing theory, the Madrasah Principal does not take a single stage in the form of pre-observation. Namely the meeting between the head of the Madrasah and the teacher to be supervised. So that teachers are often surprised because the head of the Madrasah is already in the classroom when the new teacher comes to class. This kind of practice causes the teacher to have no time to convey the learning problems faced, no time to create a familiar atmosphere first and there is no agreement on the aspects that are the focus of observation at the time of carrying out the observation. Because according to Daryanto and Tutik, there are things that need to be considered at the pre-observation stage, namely: a) Creating a friendly atmosphere with the teacher, b) Discussing the preparations made by the teacher and making agreements on aspects that are the focus of observation, c) Agreeing the observation instrument to be used [14, hlm. 206].

The next part of classroom observation is post-observation. After finishing with the end of the observed teacher's face-to-face hours, it means that classroom observations are also completed. Furthermore, entering into post-observation activities, the teacher who has been observed in class is invited to discuss one-on-one discussing the shortcomings, problems faced by the teacher and discussing the strengths of the teacher as reinforcement. This is important because there are several things that the head of the Madrasah must do after class observations as Daryanto and Tutik say, including: a) Asking what the teacher thinks about the new learning process, b) Showing data from observations (instruments and notes), c) Give the teacher the opportunity to observe and analyze it, d) Openly discuss the results of observations, especially on the agreed upon aspects, e) Provide reinforcement to the teacher's appearance, avoid the impression of blaming, e) Make the teacher find his own shortcomings, f) Provide moral encouragement that teachers are able to fix their shortcomings, g) Determine together the lesson plan and subsequent supervision [14, hlm. 207]. 
Third, the academic supervision that the head of Madrasah strives for is teacher meetings. Teacher meetings are a technique for group academic supervision [12, hlm. 87]. The head of the Madrasah in his monthly meeting said that he had carried out the group academic supervision technique. As Sah Understanding said that the teacher meeting had the same goals as the objective of academic supervision, namely; a) Unifying the views of teachers about the general concept, the meaning of education and the function of madrasas in achieving the educational goals for which they are jointly responsible, b) Encouraging teachers to accept and carry out their duties properly and encourage their growth, c) Collecting opinions on working methods that will bring them together towards achieving the maximum teaching goals in the madrasah [12, hlm. 95].

Academic supervision techniques at MI al-Huda, when seen by what Lantip and Prasojo conveyed that there are two academic supervision techniques, namely individual supervision techniques which include class visits, class observation, individual meetings, inter-class visits, self-assessment and group supervision techniques. which includes teacher meetings between teacher group studies, discussions, exchange of experiences [5, hlm. 102-108]. The researcher concluded that the first and second techniques used by the Madrasah Principals were individual academic supervision techniques and the third technique was group academic supervision techniques.

The researcher added that the Principal of Madrasah had combined the two existing academic supervision techniques, although the variety was not too many. However, the head of Madrasah uses a variety of effective and possible supervision techniques to be applied in MI al-Huda. Although there is a slight inconsistency in its implementation with the theory, the technique of academic supervision carried out has met significant difficulties until the time the research was carried out.

\subsection{Follow-up Post Academic Supervision}

The results of academic supervision need to be followed up so that what is expected with this supervision can be realized. The benefits can be felt by all education stakeholders. The follow-up that was carried out at MI al-Huda was.

\section{a) In House Trining}

The head of MI al-Huda always completes his academic supervision with discussions after the class observations have been carried out. On this occasion he discussed the shortcomings and virtues of the supervised teacher. In fact, it is not uncommon for the head to give examples of how to teach using the teaching strategies that should be implemented at that time. In addition, indirect coaching (aimed at all teachers) is also carried out at MI al-Huda (in house trining). This, as written by Hasan, said that the follow-up was carried out through a dialogical process between supervisors and those who were supervised to discuss corrective steps for the deficiencies and weaknesses experienced by the teacher in the learning process [15, hlm. 35].

\section{b) Consolidation with an assignment in the form of CAR}

In addition to the results of academic supervision records, strengthening is an assignment. Notes are used as material for evaluation by both the madrasah principal and the teacher concerned. This is as stated by Suharsimi that in order to keep what is done and what is found 
is not lost or forgotten, supervisors should make brief notes, containing important things needed to make a report [9, hlm. 19-21]. The second consolidation is an assignment in the form of conducting class visits between teachers or seeing learning carried out by other capable teachers or those appointed by the head of the madrasah. Or in other words by involving the head of the Madrasah, the teacher concerned, and it can also involve other senior teachers and conduct CAR.

\section{Conclusion}

Based on the results of the research and discussion described by the researcher in the previous chapter, the following conclusions can be drawn.

\subsection{Learning Needs Analysis}

The expectations of stakeholders, in this case are (1) the ideals of national education: students become human beings who believe and fear God Almighty, have noble character, are healthy, knowledgeable, capable, creative, independent and become democratic citizens and to be responsible; (2) the expectations of the community: want their children to have good character (akhlak al-karimah), want their children to be able to establish prayers 5 times a day, want their children to be able to read the Koran properly and correctly (3) the hopes of foundations and madrasas: students and graduates become a person who believes and has devotion to Allah SWT

The character of MI al-Huda students has diversity in terms of intelligence, activity and knowledge that they already have. The learning media used in MI al-Huda are LCD (projector), white board, loudspeaker (speaker / sound system) per class.

\subsection{Supervision of MI al-Huda Learning Tools}

The target of academic supervision at MI al-Huda is concentrated on learning, especially for educators in implementing learning to students, especially the implementation of learning in the classroom. One of the components that is supervised is a learning device, namely.

\section{a) Learning Tool Standards}

The standard of learning devices made by MI al-Huda teachers refers to the stipulated provisions, namely the RPP contains the following components: 1) school identity, namely the name of the education unit, 2) identity of the subject or theme / sub-theme, 3) class / semester, 4) Main material, 5) time allocation, 6) learning objectives, 7) basic competencies and indicators, 10) learning media, 11) learning resources, 12) learning steps, and 13) learning outcomes assessment; and the syllabus contains $\mathrm{KI}, \mathrm{KD}$, indicators, learning materials, learning activities, learning resources, and assessment instruments.

\section{b) Leaders in Guiding Teachers to Make Learning Tools}

Leaders in guiding teachers to make learning devices by holding meetings of MI al-Huda teachers for training in making learning devices and assisting in correcting individual teacher learning device errors in the principal's room before being used by teachers in the classroom. 


\title{
c) Examination of Learning Tools
}

Inspection of learning devices is carried out one week before learning devices are used in class by providing assistance to correct them if there are mistakes and the leader observes the suitability of the learning devices with practice when teaching in class with classroom observations and class visits are carried out suddenly without prior notification.

\subsection{Implementation of Academic Supervision at MI al-Huda}

Implementation time 1) class visits are carried out from time to time, 2) class observations are carried out randomly, both by the time and the teacher being observed, which is certain for each teacher once a semester in the specified month, namely: February and March in the even semester and August and September in odd semesters, 3) teacher meetings are held once a month

The aspects of academic supervision at the time of classroom observation are concentrated on; 1) pre-learning, 2) opening learning, 3) core learning activities, 4) utilization of learning media, 5) assessment of learning processes and outcomes, and 6) language use, and 7) closing. Academic supervision techniques used at MI al-Huda are: 1) individual techniques, namely: (a) class visits, (b) classroom observations, and 2) group techniques, namely teacher meetings

\begin{abstract}
Advice
The suggestions given by the researcher are; For the Head of Madrasah a). Academic supervision planning should be made in more detail, b) Before implementing academic supervision, the head of the madrasah should notify the teacher a few days in advance., C). The principal of the madrasah should make pre-observations, d). Madrasah principals carry out academic supervision of all teachers and develop the implementation of academic supervision with a clinical supervision model; For teachers, teachers should not hesitate to discuss with the head of the madrasa regarding learning problems that have been implemented so far before class observations are carried out.
\end{abstract}

\section{References}

[1] UU No. 20 tahun 2003, Sistem Pendidikan Nasional dan Penjelasannya. Yogyakarta: Media Wacana, 2003.

[2] Permendinas No. 12, Standar Pengawas Sekolah/Madrasah. Jakarta: Kementerian Pendidikan, 2007.

[3] Permendinas No. 13, Standar Kepala Sekolah/Madrasah. Jakarta: Kementerian Pendidikan, 2007.

[4] S. Khoderi, "Implementasi Supervisi secara Efektif oleh Kepala Sekolah," Majalah Media: Wahana Informasi Komunikasi dan Dedikasi, no. XLI, 2011.

[5] L. D. Prasojo dan Sudiyono, Supervisi Pendidikan. Yogyakarta: Gava Media, 2015.

[6] A. Majid, Strategi Pembelajaran. Bandung: Remaja Rosdakarya, 2014.

[7] A. Arsyad, Media Pembelajaran. Jakarta: Raja Grafindo Persada, 2005.

[8] "Permendikbud Nomor 22 tahun 2016.".

[9] S. Arikunto, Dasar-dasar Supervisi. Jakarta: Rineka Cipta, 2006. 
[10] B. Suryosubroto, Proses Belajar Mengajar di Sekolah: Wawasan Baru, Beberapa Metode Pendukung dan Beberapa Komponen Layanan Khusus, Edisi revisi. Jakarta: Rineka Cipta, 2009.

[11] S. Wahyuni dan Abd. S. Ibrahim, Perencanaan Pembelajaran Bahasa Berkarakter. Bandung: Refika Aditama, 2015.

[12] S. Sahertian, Konsep Dasar dan Teknik Supervisi Pendidikan (dalam rangka Pengembangan Sumber Daya Manusia). Jakarta: Rineka Cipta, 2008.

[13] J. Suprihatiningrum, Strategi Pembelajaran: Teori dan Aplikasi. Yogyakarta: Arruz Media, 2013.

[14] T. Rachmawati dan Daryanto, Supervisi Pembelajaran, Inspeksi Meliputi: Controlling, Correcting, Directing, Demonstration. Yogyakarta: Gava Media, 2015.

[15] Hasan dan Dkk., Pedoman Pengawasan untuk Madrasah dan Sekolah. Jakarta: Mekar Jaya, 2002. 